DOI: 10.20472/IAC.2019.048.001

\author{
ALA' RABI \\ Jerash University, Jordan

\section{BOARD CHARACTERISTICS AND CORPORATE SOCIAL DISCLOSURE: EVIDENCE FROM AN EMERGING ECONOMY}

\begin{abstract}
:
For the past twenty years, researchers have extensively debated the determinants of relationship between corporate governance and firm performance. Nevertheless, relationship between corporate governance and corporate social responsibility has received minimal attention in the extant literature, Particularly in developing countries. This paper seeks to fill the gap in the literature by examining the relationship between board characteristics and CSD. Using a sample 91 of non-financial listed companies in Amman Stock Exchange (ASE) for year ended 2017. Multiple regressions were used to confirm the relationship between board characteristics and CSD. As well as, the content analysis method was used to extract the items of corporate social disclosure from the company's annual reports.

The empirical results reveal that the level of corporate social disclosure is still relatively low compared to developed countries. Regarding board characteristics, the result show that (board size, INED) are each positive and significant relationship with the level of corporate social disclosure.
\end{abstract}

\title{
Keywords:
}

Corporate social disclosure, Board characteristics, Jordan 


\section{Introduction}

The disclosure of social responsibility is one approach where the firms can disclose their social activities to their shareholders and other stakeholders (Said, Zainuddin \& Haron, 2009). KPMG (2005) outlined the important business drivers for corporate social disclosure, including good brand and reputation, strong market position, trust of the financial market, an employer of choice and increase the value of shareholders.

There is one approach to decrease the gaps among the company and its stakeholders, that is by additional disclosure and reporting on the firms activities to the stakeholders (Said et al., 2009). Attention given to the CSD has been increasing in developed countries, and in some of the developing countries.

Very few studies have been concerned with the nature and extent of corporate social disclosure in Asian countries (Farooq et al, 2015; Jizi et al, 2013; Ranasinghe, 2011; Khan, 2010; Said, Hariri \& Haron, 2011).

In Jordan, corporate social disclosure (CSD) seemed to have received little consideration from the majority firms in terms of space devoted to disclosure, and the topics covered by the disclosure in the company's annual reports (Hindiyeh, 2007). In Jordan, the CSR activities disclosure is still not generally disseminated. There is some group of leading Jordanian companies that began to build up organized systems related to CSR activities but most of the companies revealed fragmented proceeds, and the majority disconnected from business (Hindiyeh, 2007).

Previous studies had shown that there are various factors which are drivers for corporate social disclosure such as corporate governance. Belal (2008) found the reason behind the increased interest in social disclosure in the developed countries, that is ongoing debate over the issues of corporate governance. In addition, it is considered as one of the drivers of environmental disclosure in other developing countries (Said et al., 2009).

Corporate governance is considered as the process, and structure which are employed to manage and direct the organisation, and affairs of the firms on the way to improve corporate accountability and prosperity. Thus, this study attempts to look into the governance structures that enhance the extent of CSR disclosure among public listed companies in Jordan.

Corporate governance is considered as an instrument by which the organisations are controlled and directed (Macmillan \& Downing, 1999). It is a complex subject that is impacted by a variety of factors, including manger relations, stakeholder relation, structures and practices, management compensation, and capital structure. Shlefer and Vishny (1996) point out that the corporate governance was treated with the manner in which investors assure themselves of obtaining an appropriate return on their investment, considering they are not directly involved in the decision making and internal dealings of the corporation.

Corporate governance has traditionally been with the principal-agent relationship problem (Shleifer \& Vishny, 1997). This problem is based on the hypothesis of Jensen and Meckling (1976), investors (the principals) employ managers (the agents) to run the firm on their behalf. There is a difference between the interest and objectives of investors and managers. 
Managers might be motivated to adopt investments and financial policies that benefit themselves, but harm the interests of outside shareholders. Despite the existence of this agency problem, the standard finance theory assumes that the single objective of the corporate enterprise is the maximization of shareholders' wealth, which is corporate administration acts in the best importance of all shareholders. However, corporate governance is concerned with the ways that take into consideration the interests of managers and shareholders together at the same time, and to make certain that the companies are run for the benefit of the shareholders (Mayer, 1997).

One of the informational aspects closely related to corporate governance is disclosure. Where, the boards of directors have the ability to organise the information disclosure in annual reports (Gibbins, Richardson, \& Waterhouse, 1990). Therefore, the disclosure may be a function of the constituents of boards.

Nevertheless, the board of directors in the organisation is considered to be an important tool to protect shareholders' assets and to control the management of the company. Also the board of directors is the main policy-making body, strategic planner, and acts as the authority of the company (Chobpichien, 2008). In Jordan, the board of directors in most of the listed companies in the Amman Stock Exchange (ASE) is controlled by the largest shareholders. As a result, the interests and participation of the minority shareholders are being undermined. The reason to select the board of directors is because it acts as the top management of the company and has the final say in all decisions made by the company.

Thus, this study will only focus on the relation between board characteristics and the level of corporate social disclosure.

\section{Hypotheses Development}

\subsection{Board of Director Size and Corporate Social Disclosure:}

Board of directors is a key element of the corporate governance mechanisms in overseeing the company's business conduct to ensure it is properly managed by their agents. Previous studies showed that the board of directors effectiveness is based on the consensus of the board which depends on the extent of their knowledge and expertise. Some researchers found that increasing number of the board of directors can build up better associates with the external environmental, larger board is linked with the higher external relationship, additional knowledge and higher expertise. Hence, the larger boards will gain better performance (Majumder et al, 2017; Chaudhry et al, 2016; Ranasinghe, 2011; Jizi et al, 2013).

On the other hand, other studies proposed that larger board of directors will increase the number of the problems such as increase of the communication processes and coordination problems reduce the board ability to monitor the management, the decision spread among a large group will lead to poor decision-making (Oba \& Fodio, 2012; Zhou, 2008; Htay et al., 2012).

Ranasinghe, (2011) argued that the large size of the board enables to obtain better performance and has been considered as one of the essential variables of corporate 
governance characteristics. The board of director's effectiveness depends on the consensus of the board depending on the level of expertise and knowledge. Larger members of board of directors can build up better relationship with the external environment. Chaudhry et al, (2016) argued that larger size of the board of directors the higher corporate social disclosure. Thus, it is hypothesized that:

\section{$H_{1}$ : There is a positive relationship between board size and the level of CSD.}

\subsection{Independent Non Executive Directors and Corporate Social Disclosure}

the independence non executive director consider as the important elements that enhance the effectiveness of the board in the control and supervision by effectiveness, and this in turn limits the ability of managers to act in order to serve their own interests at the expense of the interests of their clients. The independence of the Governing Council can be expressed by non-executive directors in the board of directors, non-executive directors seeking to improve their reputation through their ability and experience in the control of decisions.

Alin, et al (2012) reveal that the independence of the board has an important role in ensuring the transparency of environmental information, where a higher percentage of independent directors on board enhanced the monitoring of the financial disclosure quality and reduced the benefits of withholding information. Chaudhry et al, (2016) found that independent directors positively affect CSR disclosure. Independent directors encourage companies to invest in CSR which in return will enhance image of their companies. Majumder et al, (2017) reveal that the Agency theory suggests that independent directors pay more attention to the interests of the shareholders at the time of board decision-making process. Independent directors play a decisive role to dominate over the actions of the board of directors on CSR matters. Based on this literature, it is hypothesized that:

\section{$H_{2}$ : There is a positive relationship between INED and the level of CSD.}

\subsection{CEO Duality and Corporate Social Disclosure}

CEO duality takes place when the same individual holds both the positions CEO, as well as board chairman in the corporation (Rechner \& Dalton, 1989). There should be clarity of roles of the chairman and chief executive officer in the company, which will warrant the balance of power and authority. Were dual leadership can contribute to the lack of transparency and accountability within the company, and reduce the ability of the board to execute its oversight roles

(Ranasinghe, 2011) argued that having two different persons on the top control function (board) and execution function (management) could mitigate the agency problems. Khan et al, (2012) asserts that a dominant personality in both roles poses a threat to monitoring quality and is detrimental to the quality of disclosure. Majumder, et al(2017) found that there is insignificant between CEO duality and social disclosure, the reduced benefits from withholding information may result in enhancing quality of reporting. Therefore, it is hypothesized that:

\section{$\mathrm{H}_{3}$ : There is a positive relationship between Companies CEO Duality and the level of CSD.}




\section{Research design}

\subsection{The sampling}

This study was conducted by using non-financial listed companies in Amman Stock Exchange (ASE) for year ended 2017. there are altogether 91 companies or 48 percent of the listed company selected in 2017 for this research, which are from two sectors; industry sector which includes 47 companies and service sector consist of 44 companies.

\subsection{Dependent variables}

This study used content analysis method to measurement the level of corporate social disclosure. Content analysis has been widely used in corporate social reporting research (Haniffa \& Cooke, 2005; Guthrie \& Matthews, 1985; Ernst \& Ernst, 1978). The collected data will be from the annual report (secondary data) use to develop a CSR disclosure index, and assess the variables for board of directors, board independent, CEO duality,. Researchers consider the annual reports as the major communication tool with the surroundings.

There are five categories of social responsibility disclosure had adapted from the previous study, which were: environment, human resource, energy, products, and community involvement ( Haniffa \& Cooke, 2005; Hackston \& Milne, 1996).the reason to select this categories because it captures the areas under the CSR disclosure.

This study uses an indexing procedure to measure and evaluate the corporate social disclosure in the annual reports of Jordanian public listed companies. There are 73 items includes in the index list adapted from previous study.

In order to achieve its objectives each item will be weighted alone. The weighting will be based on the presence or the absence in the company's annual report. That is, if the item is disclosed, the company will receive a weight of one, otherwise, it will receive zero.

\subsection{Independent variables}

Table (1)

Measurement of independent variables

\begin{tabular}{ll}
\hline Independent Variables & Measurement \\
\hline Board of directors & Number of directors on the board. \\
\hline Board Independent & Percentage of non-executive directors to total directors. \\
\hline CEO Duality & $\begin{array}{l}\text { A dichotomous variable will be used for the presence of } \\
\text { dual leadership; it will take the value "1" if the CEO is also } \\
\text { chairman of the board, and "0" otherwise. }\end{array}$ \\
\hline
\end{tabular}

\section{Analysis of data}

Hierarchical multiple Regression analysis was used to examine the relationship between the corporate board characteristics namely the board size, board independence, CEO duality and corporate social disclosures. 
To determine the appropriateness of the model, several tests underlying the regression model were made which were normality, linearity, homoscedasticity and multicollinearity. In testing the model, it is involved two fold that are testing the individual independent variables and testing the overall relationship after model estimation (Hair et al., 1998). The regression model is as follows:

CSD $=\beta_{0}+\beta_{1}$ BOD $+\beta_{2}$ INED $+\beta_{3}$ CEO Duality $+\varepsilon$

Where:

CSD = Total score for each company under CSD index,

$\beta_{0}=$ The constant,

$\beta_{1} B O A=$ Board size defines number of director on the board,

$\beta_{2} I N E D=$ Percentage of non-executive directors to total directors.

$\mathrm{B}_{3} \mathrm{CEO}$ Duality = A dichotomous variable will be used for the presence of dual leadership; it will take the value " 1 " if the CEO is also chairman of the board, and "0" otherwise,

$\varepsilon=$ The error term

\subsection{Descriptive statistics}

Table (2) showed the descriptive statistics for the dependent variables of corporate social disclosure (CSD index).

\begin{tabular}{lllll}
\hline Variable & Mean & $\begin{array}{l}\text { Standard } \\
\text { Deviation }\end{array}$ & Min & Max \\
\hline CSD & .3308 & .11566 & .11 & .58 \\
Environment & .3547 & .15289 & .00 & .60 \\
Energy & .2175 & .15469 & .00 & .56 \\
Human Resources & .4285 & .11739 & .24 & .60 \\
Product & .2778 & .19131 & .00 & .67 \\
Community & .2297 & .18225 & .00 & 1.00 \\
\hline
\end{tabular}

To examine the background of the social disclosure of the 91 listed companies, the levels of corporate social disclosure in five different areas (i.e. Environmental, Energy, Human resource, Products, and Community) were determined. The level of corporate social disclosure was 33 percent in the year 2017. Moreover, the majority of the disclosures were related to human resource at an average of 42 percent of the total human resource items in the company's annual report, On the other hand, for the case of environmental themes, the level of disclosure was 35 percentages. The factor of highest disclosures from human resource is contributed by the employee profiles.

Further, the proportion of product themes in corporate social disclosure was 27 percent , then, the second lowest of corporate social disclosure in annual report comes from the community factor which had a disclosure on an average of 22 percent. The energy theme was the lowest disclosure in the annual reports where it was 21 percent which reflects that the Jordanian firms are not too concerned about energy issues. 
From the Table 2, it can be seen that the mean value for each of the social disclosure of 73 items ranges from 21 to 42 percent. With standard deviation of 11 to 19 percent, and minimum value of around 0.00 to 24 percent, and maximum value ranges from 56 to 100 percent.

\subsection{Descriptive Statistics of board Characteristics}

Table 3 provides descriptive analysis of board characteristics of non financial listed companies in Amman Stock Exchange (ASE) for the year ended 2017.

\section{Table (3)}

Descriptive Statistics of board characteristic

\begin{tabular}{lllll}
\hline Variable & Mean & $\begin{array}{l}\text { Standard } \\
\text { Deviation }\end{array}$ & Min & Max \\
\hline Independent Variables & & & & \\
\hline BOD & 8.93 & 2.528 & 5 & 14 \\
INED & .81169 & .100011 & .500 & 1.000 \\
\hline
\end{tabular}

From the sample of 91 Jordanian listed companies, the descriptive statistics of board characteristics show that the board of directors varies from 5 to 14 with a mean value of 9 percent. Regarding the proportion of non executive directors the minimum and maximum value varied from 50 percent to 100 percent, with the mean value of 81 percent.

\subsection{Correlation Analysis}

correlation analysis can detect any potential problems associated with the multicollinearity among the variables of the study (Sekaran, 2003). The table shows that all the coefficients are in the moderate level and none of them is considered high ( 0.80 or above). Therefore, the correlation results indicate that the multicollinearity is not a significant problem in this particular data set.

\section{Table (4)}

Person correlation coefficient for all variables

\begin{tabular}{llll}
\hline & BOD & INED & CSD \\
\hline BOD & 1 & $.594^{* *}$ & $.532^{* *}$ \\
\hline INED & & 1 & $.690^{\star *}$ \\
\hline CSD & & & 1 \\
\hline
\end{tabular}

${ }^{* *}$. Correlation is significant at the 0.01 level (2-tailed).

*. Correlation is significant at the 0.05 level (2-tailed).

The correlation matrix also reveals that the correlations are in the hypothesized positive direction. The result of Pearson correlation suggested that all dimensions of board characteristic are positively and significantly correlated with corporate social disclosure, namely board of directors $(r=.532, p<.01)$, independent non executive director $(r=.690, p<$. $01)$, Having discussed the correlation matrix as a prerequisite that should be fulfilled before 
any multiple regressions could be done in the variable under investigation. The next finding analyses are testing the hypotheses.

\section{Results}

\section{Table 5}

Multiple Regression Result: the Relationships between board characteristics and corporate social disclosure

\begin{tabular}{lc} 
Variables & DV: corporate social disclosure \\
& $\begin{array}{c}\text { Step1 } \\
\text { Beta }\end{array}$ \\
\hline Independent variables & $.207^{\star *}$ \\
BOD & $.258^{\star *}$ \\
INED & $-.270^{\star * *}$ \\
CEO duality & $10.239^{\star * *}$ \\
\hline F value & .310 \\
$R^{2}$ & .280 \\
Adjusted $R^{2}$ & .310 \\
$R^{2}$ change & $10.239^{* * *}$ \\
F change & \\
\hline
\end{tabular}

Note: Level of significance: ${ }^{*} p<.1,{ }^{* *} p<.05,{ }^{* * *} p<.01$

In order to examine the relationship between board characteristic and corporate social disclosure, one-step regression analysis was applied. Moreover, the corporate governance characteristics together explain about .310 of the total variation in corporate social disclosure.

The result showed that the size of the board of directors has a significant impact on corporate social disclosure where it was $P<0.05, \beta=0.207$. It shows that the larger board of directors the higher the corporate social disclosure. Therefore, $\mathrm{H} 1$ has been supported. Moreover, as regards to the independent non executive directors, the result shows that it has been a positive relationship with corporate social disclosure with the $P<0.05, \beta=0$. 258. This result indicates that the higher independent non executive directors the higher corporate social disclosure. Then, $\mathrm{H} 2$ is supported. Furthermore, the results show that CEO duality has a negative coloration on the corporate social disclosure where it was $p<0.01, \beta=-.270$. It shows that the companies with CEO duality the lower corporate social disclosure. Therefore, $\mathrm{H} 3$ is not supported as well. In general, these results give support for the assertion that the board characteristic leads to the creation of corporate social disclosure.

\section{Discussion and Conclusion}

This article has attempted to assess the relation between board of director's characteristics and corporate social disclosure in the Jordanian public listed companies. As well as, it aims to extend the previous research by examined this relationship in the context of an emerging market, where most of the previous study had ignore the Middle East in general and Jordan context in particular. Based on the full regression empirical results indicated that board of director's characteristics were positively and significantly correlated with the level of corporate 
social disclosure namely board of director and INED. The INED consider as a most significant variables that influence the level of corporate social disclosure. It means the company with higher INED the higher level of corporate social disclosure will be. As we know, independent directors play an important role in enhancing corporate image and act as a monitoring role in ensuring that the companies is properly managed by its management, resulting in more voluntary disclosure of corporate information.

Board of directors as one the most important elements of corporate governance mechanism that has ability to control and monitoring the companies. The board of director are responsible to review and approve the company's strategic plan, ensure the implementation of appropriate systems to manage this risk, determining the compensation, replacing the senior management, Review the adequacy and safety of the internal control systems, as well as include systems for compliance with applicable laws, regulations, rules, directors and guidelines. From the result it is found that the higher number of directors on the board the higher level of corporate social disclosure will be. Where, higher number of directors on the board can impact on the monitoring and control activity. As well as, the ability of the board to monitor increases as more directors are added, because they have a larger range of expertise and resources (Jizi et al, 2013; Chaudhry et al, 2016 ).

CEO duality Indicate that the same person holds both the CEO and board chairman position in the company's Khan et al, (2012).Where the chairman positions works such as leadership of the companies. In addition, the administration the board is responsibility of chairman of the board of directors. However, if the power of Chief Executive Officer and chairman of the board gathered in one person generates a strong power base, which could decrease the ability of the board's to exercise effective control (Majumder et al, 2017). Thus, the CEO duality of the companies indicates greater power to a person, which enables him to take decisions that did not maximize shareholder's wealth (Khan et al, 2012).

From the result, it is found that the companies with CEO duality the lower level of corporate social disclosure will be. Where, companies without CEO duality improve the ability of the board's to exercise effective control, and achieved independence among the management roles.

This article has a number of limitations that might warrant future research. First, an important caveat of this study is that we have only examined effects of board characteristics, on corporate social disclosure. Thus, future research may include other corporate governance mechanisms in assessing corporate social disclosure. Second, the dimension of the sample could be increased by including a longer period of time. Moreover, this study is limited to firms domiciled in Jordan. Perhaps, future research can embark on comparing corporate governance practices across different Arab countries. 


\section{References}

Belal, A. R. (2008). Corporate social responsibility reporting in developing countries: The case of Bangladesh: Ashgate Publishing Company.

Chaudhry.A.A, and Khan.I., (2016). Corporate governance and corporate social responsibility disclosure: evidence from Pakistan. Corporate Governance: The International Journal of Business in Society, 16 (5) $785-797$.

Chobpichien, J. (2008). The Quality Of Board Of Directors, Ownership Structure And Level Of Voluntary Disclosure Of Listed Companies In Thailand [HD2745. C545 2008 f rb]. (PhD), Universiti Sains Malaysia.

Farooq. S. U; Ullah.S.,and Kimani. D.(2015). The Relationship between Corporate Governance and Corporate Social Responsibility (CSR) Disclosure: Evidencefrom the USA. Abasyn Journal of Social Sciences. 8(2) 197-212.

Gibbins, M., Richardson, A., \& Waterhouse, J. (1990). The management of corporate financial disclosure: opportunism, ritualism, policies, and processes. Journal of accounting research, 28(1), 121-143.

Guthrie, J. and Mathews, M. R., (1985). Corporate Social Accounting in Australasia, Corporate Social Performance and Policy. 251-277.

Hackston, D., Milne, M. J. 1996. Some determinants of social and environmental disclosures in New Zealand companies. Accounting, Auditing \& Accountability, 9(1), 77-108.

Hindeyeh, M. (2007). Assessment of Corporate Environmental Responsibility in Jordan. Project "Launching the UN Global Compact" On Assessment of Environmentally Friendly Technology in Jordanian Industries. UNDP., from available at http://www.undp jordan.org/Portals/0/GC\%20Environment\%20report.doc.

Htay, S. N. N., Rashid, H. M. A., Adnan, M. A., \& Meera, A. K. M. (2012). Impact of corporate governance on social and environmental information disclosure of Malaysian listed banks: Panel data analysis. Asian Journal of Finance \& Accounting, 4, 1-24.

Jensen, M. C., \& Meckling, W. H. (1976). Theory of the firm: Managerial behavior, agency costs and ownership structure. Journal of financial economics, 3(4), 305-360.

Jizi.M.; Dixon.R; Salama.A, and Stratling. R., (2013). Corporate Governance and Corporate Social Responsibility Disclosure:Evidence from the US Banking Sector. Journal of Business Ethics, 125:601-615.

Khan, M. H.-U.-Z. (2010). The effect of corporate governance elements on corporate social responsibility (CSR) reporting: Empirical evidence from private commercial banks of Bangladesh. International Journal of Law and Management, 52(2), 82-109.

Khan.A.; Muttakin.M.B., and Siddiqui. J.(2012). Corporate Governance and Corporate Social Responsibility Disclosures: Evidence from an Emerging Economy. Journal of Business Ethics , 114:207-223.

KPMG. (2005). international survey of corporate responsibility reporting KPMG Global Sustainability Services,University of Amsterdam, June 2005. 
MacMillan, K., \& Downing, S. (1999). Governance and performance: Goodwill hunting. Journal of General Management, 24, 11-21.

Majumder. T. H., Akter. A, and Li.X., (2017) "Corporate governance and corporate social disclosures: a meta-analytical review", International Journal of Accounting \& Information Management, 25 ( 4),434-458.

Mayer, C. (1997). Corporate governance, competition, and performance. Journal of Law and Society, 24(1), 152-176.

Oba, V.C; and Fodio, I.M; 2012, Board Characteristics and the Quality of Environmental Reporting in Nigeria, Journal of Accounting and Management, 2 (2) 33-48.

Ranasinghe, D. N. (2011). Effect of Corporate Governance on Social and Environmental Reporting. Paper presented at the Eighth AIMS International Conference on Management, University of Kelaniya, Sri Lanka

Said, R., Hariri, H., Haron, H., \& Zainuddin, Y. H. (2011). The Extent of Disclosure of Corporate Social Responsibility in Malaysia. Developments in Corporate Governance and Responsibility, 2, 177 194.

Said, R., Zainuddin, Y. H., \& Haron, H. (2009). The relationship between corporate social responsibility disclosure and corporate governance characteristics in Malaysian.

Shleifer, A., \& Vishny, R. W. (1997). A survey of corporate governance. The journal of finance, 52(2), 737-783.

Zhou, M. M., \& Panbunyuen, P. (2008). The association between board composition and different types of voluntary disclosure: A quantitative study of Chinese and Swedish listed companies. ((Master thesis), Umeå University (Podjaman Panbunyuen). 